УДК 378.147:811.111

DOI 10.11603/me.2414-5998.2020.2.11139

Günter Beck ${ }^{1}$

ORCID https://orcid.org/0000-0002-5682-0652

O. M. Tsaryk ${ }^{2}$

ORCID https://orcid.org/0000-0003-0169-7009

N. V. Rybina ${ }^{2}$

ORCID https://orcid.org/0000-0001-6260-9039

\author{
${ }^{1}$ Independent Scholar, Augsburg, Germany \\ ${ }^{2}$ Ternopil National Economic University
}

\title{
TEACHING AND ASSESSMENT STRATEGIES IN ONLINE FOREIGN LANGUAGES DISTANCE LEARNING
}

\author{
Гюнтер Бек ${ }^{1}$, О. М. Царик ${ }^{2}$ Н. В. Рибіна ${ }^{2}$ \\ ${ }^{1}$ Незалежний науковець, Аугсбург, Німеччина \\ ${ }^{2}$ Тернопільський національний економічний університет \\ СТРАТЕГІЇ НАВЧАННЯ ТА ОЦІНЮВАННЯ В УМОВАХ \\ ДИСТАНЦИЙНОГО ВИКЛАДАННЯ ІНОЗЕМНИХ МОВ
}

\begin{abstract}
The article deals with the leading strategies for organizing students' learning and assessment in the distance teaching of foreign languages. The work analyzes available online teaching methods and forms, and the most optimal ways, types, and methods of assessing students' work on the currently available online platforms. The authors claim that pedagogical approaches to teaching foreign languages constantly require the search for new tools that can bring an element of novelty to the educational process while simultaneously increasing the interest of applicants, especially during the current (Covid-19) quarantine period.
\end{abstract}

Key words: distance learning; blended learning; flipped learning; assessment; control; tests.

Анотація. У статті розглянуто провідні стратегії організації навчання та оцінювання студентів в умовах дистанційного викладання іноземних мов. У роботі проаналізовано доступні інтерактивні методики та форми навчання, узагальнено найоптимальніші способи, форми і методи оцінювання роботи студентів на онлайн-платформах, доступних у даний час. Автори стверджують, що педагогічні підходи до викладання іноземних мов постійно вимагають пошуку новітніх засобів, які здатні привнести в навчальний процес елемент новизни, підвищити інтерес здобувачів вищої освіти, особливо в період карантину.

Ключові слова: дистанційне навчання; змішане навчання; обернене навчання; оцінювання; контроль; тестування.

Introduction. In 2020 most universities - as well as of course other educational institutions - are closed due to the coronavirus pandemic, so delivering lectures and practicals remotely has become a priority and challenge for thousands of foreign languages teachers of higher education.

Foreign languages, which are difficult to learn during the quarantine period in higher education, play an extremely important role in the education and formation of personality. Although highly difficult to learn (and teach) during the quarantine period, foreign languages nevertheless play an extremely important role in the process of the education and formation of

(c) Günter Beck, O. M. Tsaryk, N. V. Rybina personality. Knowledge and command of a foreign language is generally regarded as part and parcel of an educated and sophisticated personality, thus making education finally one of the most optimal and intensive ways to enter the world of science and culture where even spiritual values can be acquired in its process. Knowledge of a foreign language is a component of the educated and cultural personality. Education is one of the most optimal and intensive ways for a person to enter the world of science and culture. In the process of gaining education one acquires spiritual values. The content of education derives from and is constantly replenished from the cultural heritage of different countries and peoples, from various fields of everevolving science, as well as from the life and practice 
of man [2]. So foreign languages are the necessary elements which cannot be omitted in the process of studying as language competence is an essential part of a person's intelligence.

The aim - to analyze the main approaches to the study of foreign languages in higher education institutions during the lockdown period, to consider the use of accessible forms of distance learning to motivate students, and to analyze the types of distance control of students' knowledge.

Theoretical framework. Different scientific researches of educators and methodologists (O. Bigych, M. Voloshinov, O. Matnev and others) substantiate the necessity of using electronic means for teaching foreign languages. Koval studies the use of information technologies, which contribute to the real purposeful activity and high motivation of students while O. Pometun carries out an analysis on interactive teaching methods and systems. S. Nikolaev investigates the basics of the modern methodology for teaching foreign languages to reveal the purpose, tasks, principles, content, forms, and methods of student learning in future foreign language activities. N. Mayer considers the use of interactive technologies, technical and media resources to be the requirements that should be applied by the foreign language teachers. In lockdown conditions they do not have other options to work with the students. Theoretical educators (O. Bigych, O. Boretskaya, N. Borysko, S. Nikolaev) understand foreign language learning to be a complex, multifaceted process that requires regular and creative activity.

Specialists consider it as one of the main directions of foreign language introduction into the social environment, aimed at increasing the level of proficiency, carried out taking into account the state of his or her proficiency and development.

Online learning and teaching has now for many years been a crucial element of almost all language courses, but the current crisis presents one further turn of the screw since it replaced from one minute to the next all forms of "traditional" face-to-face classroom training completely. And this transition caught many teachers unprepared. With the beginning of the Corona-lockdown and its resulting "homeschooling" period, there suddenly arose an enormous demand for information on online distance learning among teachers and faculty that to a very large degree were completely or partially unexperienced in using available resources and tools, let alone the possession of the proper technical equipment at home. The crisis apparently turns out to be also the triumph of blurred video images and low sound quality.

In a webinar on online teaching provided by the German foreign language publishing house Hueber significantly more than half the participants (59\%) admitted in an ad hoc survey to possessing no experience in online teaching [11]. This dire need for information, however, was soon filled by an increasing number of online training courses imparting at least some basic knowledge as well as guidance through the wide array of tools and methodologies available on the market. This catching up on digitalization can be regarded in a wider sense also as a part of gaining the necessary media skills and proficiency for both teachers and students alike.

Currently, the question of using new methods and technologies in the educational system is very crucial. Innovations in education are those designed to resolve problem situations in order to optimize the educational process, organize favorable conditions for the assimilation of teaching material and improve the quality of education. Innovation activity not only creates the basis for the competitiveness of an institution in the educational services market, but also determines the direction of the teachers' professional growth, their creative search, and contributes to the personal growth of students. Therefore, innovative activity is inextricably linked with the scientific and methodological activity of teachers and educational research students.

The main goal of innovation in education is to develop the teacher's ability to motivate student actions, to navigate independently in the information received, to form creative critical thinking using the latest achievements of science and technology. Technological effectiveness is becoming the main characteristic of the teacher's activity today and means the transition to a higher level of organization within the educational process.

Pedagogical approaches to teaching foreign languages constantly require the search for new tools that can bring an element of novelty into the educational process and increase the interest of higher education applicants, especially during the quarantine period. The latter can be safely attributed to information and communication technologies as a component of "Blended Learning”, which are able to activate mental activity, contribute to broadening students' horizons, deepening their knowledge, development of speech and 
thinking, efficiency and productivity of the learning process, provide innovation, and mobility.

Blended learning means many things to many people, even within our relatively small online learning community. It is referred to as both "blended" and "hybrid" learning, with little or no conceptual difference of those terms among most educators. In general terms, blended learning combines online delivery of educational content with the best features of classroom interaction and live instruction to personalize learning, allow thoughtful reflection, and differentiate instruction from student to student across a diverse group of learners [17].

Specialists view blended learning as a process of organizing pedagogical interaction, which contains the following components: 1 ) direct learning in the presence of personal contact between teacher and student in the form of traditional classroom lessons; 2) independent work of students, including search tasks on Internet websites and other forms of work without the help of the teacher; 3) collaborative e-Learning, including performing various online tasks, participating in webinars, online conferences, etc. [10].

Scientists offer several approaches to an understanding of blended learning. On the one hand, we are talking about the use of new multimedia technologies in the study of foreign languages, on the other about didactic scenarios involving various methodological combinations. From a technical point of view, it is proposed to distinguish three ways of integrating multimedia technologies into the educational process: distributive (access to training materials through certain digital resources), interactive (interaction of participants with the system), and collaborative (interaction of participants with each other) [1, 12].

From an organizational perspective, there are four possible scenarios for blended learning:

1. Classroom supplemented by online resources (online grammar and vocabulary, vocabulary training exercises, closed-type tests).

2. Classroom supplemented by online components of communicative orientation (participants receive tasks via email or through a training platform controlled by the teacher, contact with native speakers in social networks, etc.).

3. Alternation of class with online classes (group work on projects, presentations, virtual contacts between participants).

4. Fully virtual learning (self-education under the guidance of a curator, a virtual audience that also facilitates group work) [13].
The mechanism of the concept of blended learning implementation as a process involves the creation of a comfortable educational information environment, a communication system that represents all the necessary educational information. Thus, there are three main components of the blended learning model used in today's educational environment:

- face-to-face training as a traditional classroom format of classroom teacher-student-interaction;

- self-study learning involving independent work of students: search for materials using a resource map, search the network, etc;

- online collaborative learning as the joint work of students and teachers online: by means of Internet conferences, skype or wiki, etc. [6].

The modern blended learning model suggests that:

- all materials of practical classes are available to students and can easily be used for self-studying, i.e. educational materials exist not only in printed form but also electronically;

- the teacher draws up a resource map, which indicates the main as well as the additional materials like Internet links for students' use during a certain language course;

- there is the possibility of online communication using tools such as chat, forum, blog, wiki;

- the development of individual and group projects is underway, which develops the skills of searching and analyzing information, teaches you to work in a team, correctly distribute responsibilities and bear responsibility for decisions made;

- audio and video lectures are used, which make the learning process simpler and more intense.

The technology of blended learning is aimed at creating students' ability to plan and organize their activities independently, focusing on the final result. Students learn to make decisions and informed choices, and to bear responsibility for them. Students develop skills and abilities to work in the information space, seek, select, and analyze information independently, present the result using various modern technologies, that is, the necessary speech and sociocultural competencies are formed.

Innovations in teaching foreign languages are associated not only with the use of new teaching methods on the basis of blended learning, new ways of organizing classes on the basis of modular training, which provides for the development of individual educational paths, or self-study using information technologies, but also with methods for assessing 
educational results in modern conditions. So, for example, a point-rating system for assessing student achievements provides a continuous comprehensive assessment of the quality of student work and is introduced at the university as a flexible and effective tool that gives students motivation to achieve high results. Increasing attention is being paid to the language portfolio or the portfolio of the student, which is a package of training materials containing the result of a learning activity in mastering a foreign language.

Educational autonomy means the willingness and ability of students to take control of their educational activities: to plan, organize, evaluate, and adjust their academic work. Meanwhile, it is equally important for students to acquire skills and abilities that allow selfeducation and self-improvement. At the same time, the choice of certain educational strategies largely depends on the individual characteristics of students, primarily the cognitive learning style [15].

As a specific type of blended learning, the term "Flipped Learning", or "Flipped Classroom", has gained wide popularity through the work of J. Bergman, A. Sams, and S. Khan. The "Flipped Learning" model is actively used to enhance the motivation of higher education students, providing conditions for free access to learning resources, collaboration in learning activities, and opportunities for personal and competence development.

Flipped Learning is a technology that involves listening to and watching video tutorials on your own, exploring additional sources, and then discussing new concepts and ideas as you go along. This model of learning replaces the elements of the submission of new material and homework, as well as encourages higher education applicants to individual work and self-development.

The Flipped Learning application allows you to: 1) increase interaction between students and faculty; 2) encourage students' responsibility for their own learning; 3) combine the traditional and constructivist approach to learning; 4) activate students' self-study; 5) keep authentic educational materials for constant review and repetition; 6) involve all students in the learning process; 7) apply an individual approach to learning; 8) acquaint students with the materials before the beginning of the class; 9) increase the motivation of higher education students to prepare for the class and to better process the material; 10) identify unclear aspects of the topic through previous tests; 11 ) organize a classroom session in the form of discussions, debates, analysis of information, which contributes to improving communication skills.

In general, the blended learning method can be used to study grammar, work with texts, foreign language films, and audio. Students should be provided with an explanation video and exercises with new vocabulary as well as grammatical structures in advance. In this way, there is a transition from passive perception of information to practical application of acquired knowledge, which in turn encourages students to take responsibility for their own education. One way to test self-contained material can be through the game-based Kahoot! Online learning platform, where teachers can create tests and assignments for their students and apply them online. Among the possible types of testing are:

- Quiz, a competition in which the participants are somewhat correct.

- Jumble, a competition in which participants must arrange fragments of the answer in the required sequence.

- Discussion an option to ask one question for discussion, questions with variants of answers are offered.

- Survey i.e. conducting a survey of the audience in order to further evaluate the results.

It is worth noting that Kahoot! facilitates a socialization of learning, because when using the platform, students usually gather around a shared screen, interactive whiteboard, or projector, sometimes working in teams. Also, using Kahoot! is one way to increase students' activity in the classroom, to revitalize them due to the atmosphere of the competition. Studies have shown that $70 \%$ of students find the platform useful and effective for knowledge testing. However, 10-20 \% of those surveyed say that performing tests in Kahoot! takes too much time. In general, the unique advantages of the platform include ease of use, originality of assessment, the ability to complete students' assignments in both classroom and non-classroom hours, and of course, a change in activity during class that animates and activates students' attention.

Most of the Ukrainian universities use the virtual classrooms provided by Moodle (Modular ObjectOriented Dynamic Learning Environment) as a base for teaching due to the quarantine. It is a flexible, open source and free learning management solution. With 100 million users (and growing) and over 100,000 Moodle sites deployed worldwide, this user-friendly eLearning platform serves the learning and training needs of all types of organizations in more than 225 
countries worldwide. It gives the opportunity to lecture, manage practical tasks and create tests for monitoring students' knowledge and skills.

Besides, it is widely used Zoom that is the leader in modern enterprise video communications, with an easy, reliable cloud platform for video and audio conferencing, collaboration, chat, and webinars across mobile devices, desktops, telephones, and room systems. Zoom Rooms is the original softwarebased conference room solution used around the world in board, conference, training rooms, and classrooms. Founded in 2011, Zoom helps universities bring teachers and students together in a frictionless environment to get more done.

Google Classroom is a free collaboration tool for lecturers and students. Lecturers can create an online classroom, invite students to the class then create and distribute assignments. Within the Google Classroom students and teachers can have conversations about the assignments and lecturers can track the students' progress.

The interactive collaboration tool Padlet, most frequently referred to as a digital post-it board, offers a simple and fast way to collect and exchange posts and information. On a shared virtual board files, links, photos, video or audio files can be collectively inserted, viewed, liked, or commented by participants. Next to teacher-generated exercises Padlet allows also for student-generated content to be posted, e.g. in the form of project work. Other stimulating activities can include social interaction by commenting on other posts, brainstorming, or a summary of results. An important and integral part of training in any educational form remains the control of the students' learning activities, including testing - even more so with distance learning methods. At the same time, a number of psychological and pedagogical problems arise in the use of Internet testing in distance learning. In connection with the increasing role of information and communication technologies in the educational process, there is a tendency to move from traditional forms of monitoring the definition of education quality to computer testing. The effectiveness and feasibility of such control using these tools is largely determined by the quality of the material for testing, its goals, the methodological justification of their consistency, the systematic nature of its conduct and the specifics of the academic discipline itself [7].

The following conditions for the effectiveness of control are to be distinguished:
1. The adequacy of forms and types of control of the audited activity.

2. Reliability of control, which means not the random, but the regular nature of the results obtained, their stability and reproducibility, as well as independence from the identity of the lecturer (the reliability of control is closely related to its objectivity, which is expressed in the availability of standards and keys for the inspector, which allows control promptly and unambiguously).

3. The practicality of control, which allows the examiner to use it quickly within the framework of the usual educational process, minimizing the time spent on its organization and processing of results. The effectiveness of control also largely depends on how it meets the requirements of didactics and methods of teaching foreign languages. The main requirements for control are its objectivity, regularity, differentiated nature, as well as clarity and clarity of the formulation of control tasks [8].

When teaching a foreign language, the following steps seem to be necessary for the correct organization of assessment:

1. Conducting both full-time and distance learning. The discipline "foreign language" cannot be completely reduced to the use of information and communication technologies. It is important at least at the beginning of the course to conduct several full-time classes in order to get to know students personally and determine the level of language proficiency for each student. If conducting full-time classes for some reason is not possible, it can be replaced by a webinar or online conference 2. Formulating tasks in such a way that they are not plain, ordinary copying exercises (for the students). For example, when developing a foreign language written discourse, it is better to give students creative assignments (write an essay on a problematic topic; a review of a film or book, etc.), rather than just assignments for word substitution or paraphrasing. During the writing of such assignments, you need to express your opinion that will reduce the charge-off percentage and also make it easy to identify the student who is writing off (the teacher is aware of the student's knowledge level, which allows him to more correctly evaluate the work) [9].

The main difference between traditional control tasks and test tasks online is that the latter always include measurements using a special scale (matrix). Thus, the assessment according to the test results is more objective and independent of the possible subjectivity 
of the teacher. Meanwhile, the standard form of tasks provides efficiency in work and ease of calculation of results. Based on the foregoing, we conclude that there are such control functions: 1) diagnosis 2) corrective 3) educational assessment. There are also educational, stimulating, and motivational forms of assessment. A stimulating effect on student learning is provided by control, which increases motivation. The sources of the learning function are the consolidation and the improvement of knowledge, skills and abilities in the process of performing control tasks. Testing of knowledge of a foreign language takes place in the context of general, expanding trends in the application of tests in various fields of training and control. In the subject-specific field of linguodidactic testing, one can now speak of an exceptionally positive attitude towards tests as a means of measuring language knowledge and skills [7].

Conclusions and Prospects for Research. In general, distance teaching technologies can be a powerful means of getting education to students especially under lockdown conditions. However, the crisis made visible another grave issue that should at least briefly be addressed: The lack of appropriate devices in combination with limited or even no access to the Internet even increases the already existing inequalities in the educational systems, as for example P. Munzinger recently stated in the Sueddeutsche Zeitung. It is also

\section{List of literature}

1. Гребінник Л. В. Інструментарій та вимоги до студента й викладача при застосуванні змішаного навчання іноземним мовам / Л. В. Гребінник // Використання моделі змішаного навчання при викладанні іноземних мов : тези доповідей. - К., 2018. - С. 26-29.

2. Кремень В. Г. Філософія людиноцентризму в стратегіях освітнього простору / В. Г. Кремень. - К. : Педагогічна думка, 2008. - 424 с.

3. Методика навчання іноземних мов і культур: теорія і практика : підручник для студ. класичних, педагогічних і лінгвістичних університетів / [О. Б. Бігич, Н. Ф. Бориско, Г. Е. Борецька та ін.] ; за заг. ред. С. Ю. Ніколаєвої. - К. : Ленвіт, 2013. - 590 с.

4. Пометун О. Сучасний урок. Інтерактивні технології навчання / О. Пометун, Л. Пироженко. - К., 2004. - 192 с.

5. Пометун О. Як оцінити діяльність учнів на інтерактивному уроці / О. Пометун // Доба. - 2002. - № 2. C. 2-6.

6. Рафальська О. О. Технологія змішаного навчання як інновація дистанційної освіти / О. О. Рафальська // highly questionable if a smartphone alone is the adequate technical access for advanced online distance learning. Here, learning success comes only with the necessary and equally distributed technical equipment.

In order to increase the effectiveness of new information technologies in teaching, it is necessary to create a system that provides a proper understanding of the nature of teaching, the role of the lecturer and students in this process, the relationship between the lecturer and students, and, of course, equipping their workplaces for this type of teaching and studying with the technology best suited for the purposes intended. Besides, it can be noted that the use of online tests in foreign language lessons is one of the prerequisites for the modern educational process in general. The huge advantage of online tests in comparison with other forms of work, along with the introduction of electronic communications and distance learning in the educational process, will contribute to the growing role of working with test tasks in foreign language classes in modern higher education institutions. This allows us to conclude that the assessment of the quality of teaching foreign languages on the test material remains a serious problem, and the relevance of its solution is increasing, especially in connection with the transition to distance learning, universal test exams in the form of a single state exam in foreign languages.

Комп’ютерно-інтегровані технології: освіта, наука, виробництво. - 2013. - № 11. - С. 11.

7. Саидмуратова У. Р. Тестирование как метод контроля и мониторинга знаний при обучении иностранным языкам в дистанционном образовании / У. Р. Саидмуратова // Молодой ученый. - 2019. № 19 (257). - С. 368-370.

8. Хакимова А. А. Использование системы управления обучением Moodle для организации и проведения контроля при обучении английскому языку / А. А. Хакимова, Л. В. Михалёва. - Режим доступа : http://www.lib. tsu.ru/mminfo/000349304/18/image/18-115.pdf.

9. Чекун О. А. Развитие иноязычного письменного дискурса студентов-бакалавров посредством социальных сервисов / О. А. Чекун, Ю. В. Наволочная // Вестник МГГУ им. М. А. Шолохова. Сер. «Филологические науки. - 2013. - № 4. - С. 5-79.

10. Bonk C. J. Handbook of blended learning: Global perspectives, local designs / C. J. Bonk, C. R. Graham. - San Francisco, CA : Pfeiffer Publishing, 2006. - 571 c. 


\section{"PROFESSIONAL AND COMMUNICATION CULTURE OF THE FUTURE DOCTOR: LINGUISTIC, PEDAGOGICAL AND PHILOSOPHICAL ASPECTS”}

11. Hueber Verlag. Webinar Online Unterrichten: Kompaktkurs am 17.04.2020. - URL : https://bit. ly/2W5CJzR (last accessed 27.04.2020).

12. Effective methods in foreign language teaching of medical students / N. Yelahina, N. Fedchyshyn, H. Klishch, T. Horpinich // Медична освіта. - 2019. - № 1 (81). C. 48-54.

13. Kranz D. Blended Learning - von der Idee zur Tat, vom Konzept zur Realisierung: Zwei Berichte aus der pädagogischen Praxis der Lehrerbildung. Zeitschrift für Interkulturellen Fremdsprachenunterricht 10/1 / D. Kranz, B. Lüking. - Darmstadt, online verfügbar unter. - URL : http:// zif.spz.tudarmstadt.de/jg-10-1/docs/KranzundLueking2005. pdf.

\section{References}

1. Grebinnyk, L.V. (2018). Instrumentarii ta vymohy do studenta i vykladacha pry zastosuvanni zmishanoho navchannia inozemnym movam [Toolkit and requirements for student and teacher in the application of blended learning in foreign languages]. Vykorstannia modeli zmishanoho navchannia pry vykladanni inozemnykh mov: tezy dopovidei - Use of Blended learning model when teaching foreign languages: Theses. Kyiv [in Ukrainian].

2. Kremin, V.G. (2008). Filosofiia liudynotsentryzmu $v$ stratehiiakh osvitnoho prostoru [Philosophy of humancentrism in strategies of educational space]. Kyiv: Pedahohichna dumka [in Ukrainian].

3. Bigych, O.B., Borysko, N.F., \& Boretska, G.E. (2013). Metodyka navchannia inozemnykh mov i kultur: teoriia i praktyka: pidruchnyk dlia stud. klasychnykh, pedahohichnykh i linhvistychnykh universitetiv [Methods of teaching foreign languages and cultures: theory and practice: a textbook for students of classical, pedagogical and linguistic universities]. Nikolaieva, S.Yu. (Ed.). Kyiv: Lenvit [in Ukrainian].

4. Pometun, O., \& Pirozhenko, L. (2004). Suchasnyi urok. Interaktyvni tekhnolohii navchannia [Modern lesson. Interactive learning technologies]. Kyiv [in Ukrainian].

5. Pometun, O. (2002). Yak otsinyty diialnist uchniv na interaktyvnomu urotsi [How to assess student activity in an online lesson]. Doba - Day, 2, 2-6 [in Ukrainian].

6. Rafalska, O.O. (2013). Tekhnolohiia zmishanoho navchannia yak innovatsiia dystantsiinoi osviti [Blended learning technology as a distance learning innovation]. Naukovyi zhurnal "Kompiuterno-intehrovani tekhnolohii: osvita, nauka, vyrobnytstvo - Scientific Journal “Computerintegrated technologies: Education, Science, Production, 11, 11 [in Ukrainian].

7. Saidmuratova, U.R. (2019). Testirovanie kak metod kontrolya i monitoringa znaniy pri obuchenii inostrannym yazykam v distantsionnom obrazovanii [Testing as a method
14. Munzinger P. Vorübergehend nicht zu erreichen / P. Munzinger. - Süddeutsche Zeitung. - 11, April 2020. URL : https://bit.ly/2Y8V3dW (last accessed 27.04.2020).

15. Oxford R. L. Teaching and Researching: Language Learning Strategies. Pearson Lngman, 2011. - 360 p.

16. Rybina N. Language competence as an essential part of person's intelligence / N. Rybina, N. Koshil, O. Hyryla // Психолого-педагогічні проблеми становлення сучасного фахівця : зб. наук. статей Національної академії Національної гвардії України, матеріали Міжнар. наук.практ. конф. (Україна, Харків, 18-19 трав. 2018 р.). - Х. : ХОГОКЗ, 2018. - С. 267-274.

17. Watson J. Blended learning: The convergence of online and face-to-face education / J. Watson. - North American Council for Online Learning, 16. - URL : https://files.eric. ed.gov/fulltext/ED509636.pdf.

of control and monitoring knowledge in teaching foreign languages in distance education]. Molodoy uchenyy - Young Scientist, 19 (257), 368-370 [in Russian].

8. Khakimova, A.A., \& Mihalyova, L.V. Ispolzovanie sistemy upravleniya obucheniem Moodle dlya organizatsii i provedeniya kontrolya pri obuchenii angliyskomu yazyku [Using the Moodle Learning Management System to organize and conduct control in teaching English]. Retrieved from: http://shhshhshh.lib.tsu.ru/mminfo/000349304/18/ image/18-115.pdf [in Russian].

9. Chekun, O.A., \& Navolochnaya, Yu.V. (2013). Razvitie inoyazychnogo pismennogo diskursa studentov-bakalavrov posredstvom sotsialnykh servisov [Development of foreign language written discourse of bachelor students through social services]. Vestnik MGGU im. M.A. Sholohova. Ser. "Filologicheskie nauki" - Herald of MSU named after M.A. Sholohov, 4, 75-79 [in Russian].

10. Bonk, C.J., \& Graham, C.R. (2006). Handbook of Blended Learning: Global Perspectives, Local Designs. San Francisco, CA: Pfeiffer Publishing.

11. Hueber Verlag. Webinar Online Unterrichten: Kompaktkurs am 17.04.2020. Retrieved from: https://bit. ly/2W5CJzR.

12. Yelahina, N., Fedchyshyn, N., Klishch, H., \& Horpinich, T. (2019). Effective methods in foreign language teaching of medical students. Medychna osvita - Medical Education, 1 (81), 48-54.

13. Kranz, D., \& Lüking, B. (2005). Blended Learning von der Idee zur Tat, vom Konzept zur Realisierung: Zwei Berichte aus der pädagogischen Praxis der Lehrerbildung. Zeitschrift für Interkulturellen Fremdsprachenunterricht 10/1. Darmstadt. Retrieved from: http://zif.spz.tudarmstadt. de/jg-10-1/docs/KranzundLueking2005.pdf.

14. Munzinger, P. Vorübergehend nicht zu erreichen. Süddeutsche Zeitung. 11. April 2020. Retrieved from: https:// bit.ly/2Y8V3dW. 
15. Oxford, R.L. (2011). Teaching and Researching: Language Learning Strategies. Pearson Longman.

16. Rybina, N., Koshil, N., \& Hyryla, O. (2018). Language competence as an essential part of person's intelligence. Psykholoho-pedahohichni problemy stanovlennia suchasnoho fakhivtsia. Zbirnyk naukovykh statei Natsionalnoi akademii Natsionalnoi hvardii Ukrainy. Materialy mizhnarodnoi naukovo-praktychnoi konferentsii - Psychological and pedagogical problems of becoming a modern specialist: Coll. of Scient. Articles of the National Academy of the National Guard of Ukraine, Materials of International Scientific-practical Conf. Kharkiv: HOHOKZ [in Ukrainian].

17. Watson, J. Blended learning: The convergence of online and face-to-face education. North American Council for Online Learning, 16. Retrieved from: https://files.eric. ed.gov/fulltext/ED509636.pdf.

E-mail address for correspondence: tsarykolga@gmail.com 